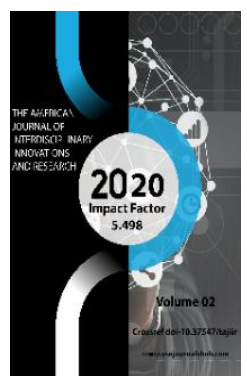

\title{
Detailed Analysis Of The Basics Of The Khojagon Sect (Way) In The Work "Rashakhot"
}

Journal Website: http://usajournalshub.c om/index,php/tajiir

Copyright: Original content from this work may be used under the terms of the creative commons attributes 4.0 licence.

\author{
Bahriddin Umurzoqov \\ Doctor Of Philological Sciences (Phd). Senior Lecturer, Department Of Source Studies And \\ Sufi Hermeneutics, Tashkent State University Of Oriental Studies, Uzbekistan
}

\section{ABSTRACT}

This article is dedicated to the 16th century scholar Fakhruddin Ali Safi ibn Husayn Waz Kashifi Hirawi (1463-1533), a mature manaqibnavis and tazkiranavis who lived and left a rich scientific legacy. Fakhruddin Ali Safi ibn Husayn Waz Kashifi Hirawi's (1463-1533) work "Rashakhot aynu-l-hayat" (Drops of the spring of life) dedicated to Hodja Ubaydullah Ahror and in this work The description of the Eleven Blessed Phrases, which is explained in detail under the name, in particular, is devoted to the study and interpretation of the phrase "Hush dar dam" (remembering Allah at all times, engaging in the remembrance of Allah), the first foundation of the first Khojagan sect.

\section{KEYWORDS}

Ali Safi Kashifi Hirawi, "Rashakhot aynu-l-hayot”, rashha, Khoja Yusuf Hamadoni - Khoja Abdulkhaliq Gijduvani - Khoja Baha-ud-Din Naqshband, yozdah kalimot-i qudsiya-i Khojagon (eleven bases of Khojagon sect), "Hush dar dam" (every moment is the remembrance of Allah, to engage in the remembrance of Allah) blessed phrase.

\section{INTRODUCTION}

The essence of medieval Muslim Eastern mysticism, in particular, the essence of our classical literature, along with the literary sciences, cannot be fully understood without 
Islamic spirituality, the Qur'an, hadiths, and especially mysticism.

It is known that the period when the first mystical works began to appear is the second half of the ninth century. From the beginning of the 10th century to the 13th century, a number of famous works of mysticism were written. In particular, such works as Gulabadi's “Kitabu-t-Ta'arruf”, Abdulkarim Qushayri's "Risolatu-I-Qushayriyya”, Hujviri's “Kashfu-Imahjub", and Ibn Zayyat's "at-Tasawwuf" are indeed mystical from today's point of view. are the most important books in which the theoretical issues of science are described. His works on the complex issues of Sufism include Hakim Termizi's (d. 908) "Khatmu-Iviloya", Muhyiddin Arabi's (d. 1224) "Futuhot", "Hikam", Fariduddin Attar's "Tazkiratu-Iawliyo", Later, important works were written by Muhammad al-Ghazali (d. 1111), such as "Ihyo-i Ulumi-d-Din" and "Kimya-i Saodat", which explained the mysticism of Ahl asSunnah wa'l-Jama'ah in connection with the Shari'ah.

\section{THE MAIN RESULTS AND FINDINGS}

Sheikh Abdullah Ansari, known as "Pir-i Heart" in the scientific community of Herat, has a great place. His mystical work, called atTabaqat, which is actually a translation of Abu Abdurahman Sulami's Tabaqatu-s-Sufiyya (Layers of the Sufis), is also a kind of mystical work. Later, two more important tazkiras were written - Nafohatu-I-uns and Nasoyimu-Imahabba (Alisher Navoi said in the introduction to this work that Nasoyim is a translation of Nafohatu-l-uns. This fact is also mentioned in the preface of the author's "Arba'in". We need to study and analyze this situation in depth, without immediately concluding that it is a "traditionally independent work" - B.U.) Undoubtedly, one of the rarest manaqib-tazkirs written under the influence of these definitions and classifications is "Rashakhot aynu-l-hayat" (drops from the spring of life) by Fakhruddin Ali Safi. Rashakhot is one of the best examples of mystical literature and, in general, historical fiction in our classical literature.

Without literary and mystical sciences, it is difficult to understand the essence of the literary and scientific heritage of Fakhruddin Ali Safi, in particular, the essence of his work "Rashakhot",written in honor of Khoja Akhror Vali, which actually contains detailed information about the Khojagan sect and the Mashaik.

In the "Introduction" section of the work "Rashakhot" entitled "Article", the foundations of the Khojagon sect (path) are described in detail. The second important point in the play, which expresses the essence of the Khojagon sect, is the interpretation of the rules, terminology and etiquette of this sect. Rashakhot's dhikr "Khoja Abdulkhaliq Gijduvani quddisa sirruhu (tomb, full of light)" contains a total of thirteen rashhacommentaries (small sections) under the title "rashha". The word "rashha" literally means "a drop, sweat running down the forehead." The word "Rashakhot" is the plural form of "rashha" and means "drops." When Ali Safi said "Rashakhot" and "rashha" in his work, he used these two words not in a lexical sense, but in a terminological and symbolic sense, that is, in the sense of "drops of enlightenment."

They talk about the following topics:

1- rashha. The first verse, which begins with "I will make a will for you, my child ...", is based on the "Testament" of Khoja Abdulkhaliq Gijduvani. 
In the following verses, the first eight Quds (blessed, holy) words of Khoja Abdulkhaliq Gijduvani, and then three more of the holy words, ie "kalimot-i wuqufat" (expressions about the situation), are listed one by one. It is often referred to by researchers as the "Fundamentals or Principles of Naqshbandi": "Hush dar dam", "Nazar bar kadam", "Safar dar vatan", "Khilvat dar anjuman", "Yod kard", "Bozgasht", "Nigoh dosht", "Yod dosht":

اي ن ا ست خو اجه ح ضرت قُ د سد يهء ك لمات از هو و و ر شحه

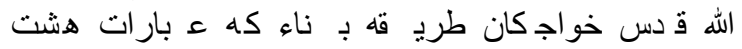

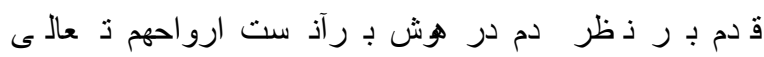

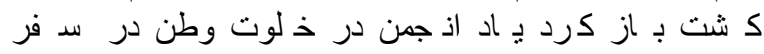

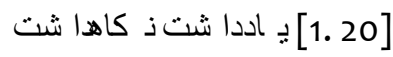

2- Rashha. In the statement, "Hush dar dam" (every breath is a face of awareness).

3- Rashha. "Nazar bar kadam" (be able to keep your eyes open while walking, be imaginative in your behavior, be polite and get rid of selfishness).

4- Rashha. In the statement "Safar dar vatan" (to travel from human qualities to qualitative qualities, to get rid of bad habits and to have praiseworthy qualities).

5- Ashha. In the statement, "Khilwat dar anjuman" (to be with the people outwardly, and to be with Allah inwardly).

6- Rashha. In the statement "Yad kard" (continuous remembrance of Allah with the tongue or the tongue).

7- Rashha. In the statement, "Boz Gasht" (The purpose of zikrullah is to find Allah and His approval).

8- Rashha. In the statement, "Nigoh dosht." (muraqaba-i hawbat, that is, not to divide one's thoughts and ideas during zikrullah).
9- Rashha. "Yod dosht" (in the eye of the beholder, that is, to succeed in concentrating anxiety).

Much has been written about the blessed words of the Khojagan sect, and the first four of these eleven phrases are attributed to Khoja Yusuf Hamadoni, four to Khoja Abdulkhaliq Gijduvani, and three to Khoja Baha-ud-Din Naqshband. [2. 96]

According to S.Sayfulloh, "Hazrat Khoja Abdulkhaliq Gijduvani was the real founder and builder of the Khojagan series, based on eight of the 11 methods of the Naqshbandi sect. The other three phrases refer to Khoja Baha-ud-Din Naqshband" [2. 95].

But Turkish researcher Dr. Nejdat Tosun disagrees in his monograph. [3. 334] In our opinion, N. Tosun's scientific analysis and conclusions about these Khojagon phrases are noteworthy. Indeed, the eight blessed phrases of Khojagan actually existed even before Khoja Abdulkhaliq Gijduvani. The remaining "three wuqufs" (three blessed phrases), that is, "Wuquf-i zamani" (let a person be aware of his condition, that is, whether he is grateful or apologetic), and "Wuquf-i adadi" (observance of the number in zikrullah). This is because the number of parishioners serves to accumulate worries) and the "Wuquf-i-kalbiy" (awareness of the heart, that is, not giving any place in the heart except the remembrance, remembrance and love of Allah).

Thoughts and wisdom related to these three blessed expressions are also found in the works of mystics before Khoja Baha-ud-Din Naqshband, for example, Abu Abdurahman Sulami's ال صوف ية ط بـ قات Tabaqatu-s-Sufiyya (Layers of the Sufis) and Abdul Karim ال تصوف ع لم ف ى الـ قد يريدة الر سالة Qushayri's In Risolatu-l-Qushayriyya fiy ilmi-t-tasawwuf (The Treatise of Qushayriy on the Science of 
Sufism), Gulobodi'ال تصوف الهي لمذه ال تعرفي "At-Taarruf li-mazhabi ahli-t-tasawwuf" (Introduction to the way of Sufis) are also found in the pamphlets [4]. In our view, Khoja Baha-ud-Din Naqshband has succeeded in seriously and fully implementing these last three rules, the three principles in his leech practice. For this reason, these three words (blessed phrases) are attributed to Hazrat Naqshband. Indeed, in the sect, practice is more important than theory as a righteous practice.

In this regard, it should be noted that in the treatises of Khoja Yusuf Hamadoni, these first holy words (blessed phrases) are not mentioned under the names "Hush dar dam", "Nazar bar kadam", "Safar dar vatan", "Khilvat dar anjuman". For example, in the pamphlet "Odob-i tariqat" by Khoja Yusuf Hamadoni, we see that the basics of the sect are described in detail as "uzlat", "nafs riyazat", "nafs tarbiyasi". [2] The reason why the first four holy words (blessed phrases) are attributed to Hodja Yusuf Hamadoni has not been proven in modern mysticism and has not been studied in depth.

After commenting on the blessed words of the Khojagan sect, Ali Safi made a very important point. According to him:

بـ ندا شت هه اي ن غ ير و

"Apart from these (that is, from these blessed expressions) are all conceit, that is, arrogance and pride (arrogance and self-deception)." [638] That is, those who claim to belong to the Khojagan Sect (way) should engage in activities that are not related to these eight words, and any behavior that does not comply with the requirements of these words (blessed expressions), all actions, "enlightenments" (that is, trying to present oneself as a scientist and being eloquent for this purpose), so to speak, are to build oneself up, to waste one's precious life.

"What is the main purpose of explaining these terms as "alfoz-i mustalaha'?" the question may arise. According to Ali Safi, it is known that Hazrat Khoja Abdulkhaliq sarhalqa-i silsilai khojagan (the leader of the khojagan sect), so knowing his "mustalahot" (specific words) is the blessed spiritual path he started, that is, the khojagan sect. means to know well:

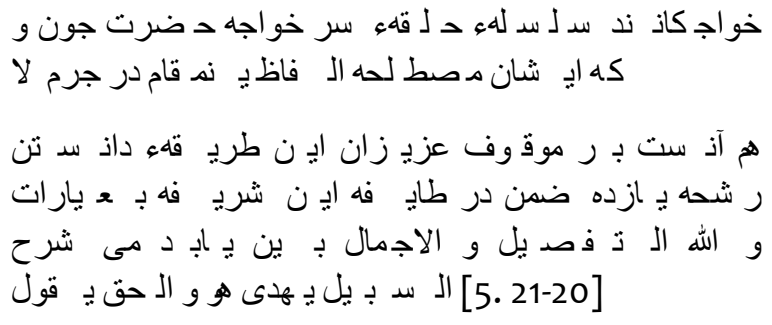

It is known that the main purpose of the religious and mystical works of our classical literature is to"educate man in the moral spirit" and, as a result, to help him to become a perfect man. Hence, the goal set forth in the eight rules of the Khojagon sect above is, in fact, the attainment of religious, first of all, spiritual and moral perfection.

Thereafter, this chapter provides detailed information on these eleven principles of the Khojagon sect in eleven verses.

The first holy word of the Khojagan sect, as stated above, دم در هو It is called "Hush dar dam" (to be awake with the remembrance of Allah at every moment, that is, not to forget the remembrance of Allah for a moment). In the last hundred years, the researches of almost all foreign mystics have given a brief account of the phrase "Hush dar dam", but the original meaning and essence of this phrase, and how it is used in practice, have not been mentioned at all. Ali Safi in his work "Rashakhot" commented on this first 
principle in detail (extensive, perfect, complete):

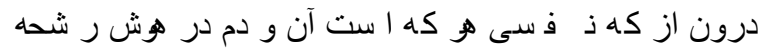

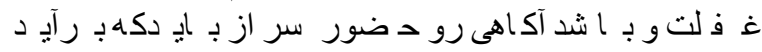

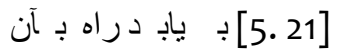

According to him, the meaning of this phrase is: "Every breath I take comes from within, let it be in the face of peace and awareness, and let ignorance never find its way to it."[6. 38]. That is, breathing means life, vitality. Every breath taken causes a spiritual force in the human body, that the expenditure of spiritual energy is not free from the remembrance of the commands of Allah.

It was here that Ali Safi tried to shed more light on the subject by quoting the famous Khojagan mashayik. First of all, he was a contemporary of his, the great priest of Heart. We can learn the meaning of these words of Mawlana Kashgari from several "rashhas" (small chapters) in a special chapter in which he is mentioned in "Rashakhot". The following words of Mawlana Kashgari, which testify to the commentary of "Hush dar dam", are clearly stated in those places: "O people! There is ranje in every breath, it passes, you have to be aware. Haqq subhanahu wa ta'ala (God of the worlds, i.e. Allah ta'ala) is always present and watching. You should be ashamed of Allah and you should not be ignorant of Him. God is very close to man (ie, spiritually close - B.U.). It is necessary to be in the same belief (trust and understanding). It is necessary to be polite everywhere - both when you are alone and when you are among people. You should be ashamed to stretch your legs even when you are alone at home. In particular, it is necessary to sit shyly on the floor (toilet), with his head down and eyes closed. It is necessary to be truthful to the Almighty, both openly and secretly. It is this etiquette that is known to those who sincerely follow it (Emphasis is ours - B.U.). Let man always behave in the midst of outward and inward manners. Outward etiquette is the observance of what the Shari'ah commands and forbids. Always perform ablution, increase istighfar (repentance, say the word "Astagfirullah" sincerely), and say as little as possible. The most important thing in etiquette is to protect the heart from the good and bad thoughts and views of strangers. Both of these (i.e., much talk and the words, thoughts, and opinions of those who are alien to the sect) have the same effect in diverting the tax (belonging to the sect) from Allah, the Creator.

This tribe has acquired all this, and will always be alive with the memory of the Almighty, and will disappear from itself. If they go to ruku 'in prayer, I do not welcome them, and if they are free (they do not want to raise their heads from ruku'), and if they prostrate in prayer, I do not welcome them, if they do not bow down in prostration. This tribe is the most gentle of all (the heart is very delicate, always in monotheism and devotion), They will not be able to bear it until they turn a blind eye to the remembrance of Allah. The prophets are jealous of their condition. And their jealousy is in terms of their ability to approach Allah ..." [6. 163-166]

It can be seen in the Risala-i Qushayriya that this issue is mentioned in a place called ال حال al-Holu. According to Imam Qushayri, the situation is related to the heart, and being able to persevere in it ensures the spiritual growth of a believer. [7]

In his commentary on the word "Hush dar dam", Ali Safi also quoted the following words of Khoja Ubaydullah Ahror: In this way, "hifz-i nafas", that is, all the breaths of a person should be on the basis of peace and awareness. For someone who can't hold his 
breath, "falonche nafas gum karda", they say, murad so-and-so has destroyed tariq and ravishi (i.e., way and purpose)". [6.38]

According to Rashakhot, according to Khoja Baha-ud-Din Naqshband, this way, that is, taking the path in the sect, is by controlling the breath. Righteous man thinks neither of the past nor of the future, but strives to keep his breath. To do this, it protects, that is, controls the entry and exit of the breath, and even between the two breaths, so that the heart does not find a careless way in the entry and exit of the breath [6. 38]. From this definition it is possible to understand why the Khojagon sect, as well as the Naqshbandi leech, are recognized as "tariqat-i oliya", that is, the highest, the highest sect, at all times and everywhere. Indeed, in sects other than Khojagon, such specific requirements do not strictly exist. For example, the practice of chilla is required in other sects (for example, in the Qadiriyya leech), but in Khojagon it is a "Khulvat Dar Anjuman", that is, during ablution with the people, in daily activities, with constant ablution, remembrance, contemplation, murakaba (Allah is always present and watchful. There are specific requirements, such as walking). We will discuss this in more detail later, in the statement of the study of the holy word of the Khojagan sect "Khulvat Dar Anjuman". In this regard, Ali Safi in "Rashakhot" narrated an important information given by his teacher Mawlana Abdurahman Jami at the end of his work "Sharh-i Rubaiyat" (Commentary of the Rubaiyat). According to Mawlana Jami, Sheikh Abuljanab Najmu-l-Kubaro (ie, Sheikh Najmiddin Kubro-BU) wrote in his treatise Fawatih al-Jamal: Zikr, that is, the remembrance of $\mathrm{Hu}$, which refers to the unseen identity of Allah, is present in the breaths of all living beings. Even in the word "Allah", the basis is "Hu". Indeed, in the word
"Allah", "alif and lam" is for definition, and the threat in "lam" is for exaggeration. There is a "ho" at the end of the inhaled and exhaled breaths. This is dhikr".[6.40]

It has been rightly pointed out that the "hu" that a righteous person (a member of a sect) breathes is reminiscent of Allah, the Exalted. Every breath you take is a treasure. But, alas, most people are unaware of this Divine gift and are ungrateful. The second meaning of the word "hush dar dam" is that the member of this sect should pay attention to the situation and status within himself. [8. 1]]

It is also stated in the hadiths that the name "Hu" is the Name of the Greatest, and therefore this blessed Divine Name is a dhikr of specific beings and even of intelligent people who are unique.

Sources about dhikr quote the following important words of Hoja Alouddin Attor:

"In our time, most people recite with their stomachs, not their hearts. The goal is not to mention a lot. The murid (member of the sect) mentions dhikr three times in each breath. Let him start from the right side and let it fall on his heart ... Before the Fajr prayer and after the evening prayer, let him continue in zikrullah in a deserted place. He can recite dhikr nine or or eighteen times in one breath. If he recites dhikr eighteen times and there is no result, then he begins dhikrullah from the beginning. [9.160]

Ali Safi's narrator, Khoja Ubaydullah Ahror, said in one of his treatises, which are considered holy words: "The essence of dhikr is that the heart of the dhikr should never forget Allah on the condition of love and reverence.":

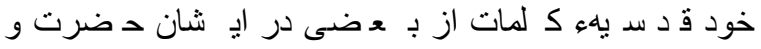

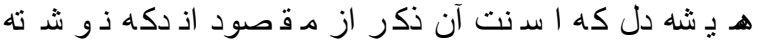


و مح بت ب و صف بـاشد ذه سد بحا حقّ بـه آكاد

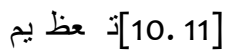

In his commentary on the word "Hush dar dam", Ali Safi quoted two rubai. The first rubai:

ع ين ساحل بـ ر ع لمب حر ز ماذ ده اى رب اع به

شد ين ساحل بـ رو ف راغ ست بـ حر در

كوذ ين موجز ذظر صد فى بـ ردار

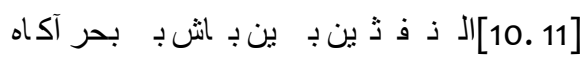

Ey monda zi bahr-i ilm bar sohil-i ayn,

Dar bahr farog'at-ast-u bar sohil shayn.

Bardor Safiy nazar zi mavj-i kavnayn,

Ogoh ba bahr bosh bayna-n-nafasayn.

This rubai belongs to the pen of Ali Safi, and the word "Safiy" in the third verse is the poet's nickname. The poet here points out that the rubai belongs to his pen. However, in the 2003 and 2004 editions of Rashakhot, the word was changed to "sarfi" [6. 38].

Meaning: O you who remain on the shore

without entering the sea of knowledge,

There is relaxation at sea and unhappiness on the beach.

Stop being obsessed with Kavnain waves,

Between the two breaths, beware of the sea!

The second rubai quoted in the commentary on the word "hush dar dam" is as follows:

شذ ناس حرف اى آمد هي ت غ يب هـ

ا ساس حرف آن بـ ر بـ ودد ر را اذ فاس و

هو اس و ام يد در حرف آن از آكه بـ اش

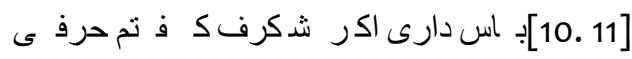

“Hu” g‘ayb-i huviyyat omad, ey harf-shunos,
Va anfos-i to'ro buvad bar on harf asos,

Bosh ogoh az on harf dori ummed-u haros,

Harfe go'ftam shugraf agar dori pos.

Meaning: "Yes" is the letter of the essence of God's existence,

O researcher, every breath you take is based on this letter.

In moments of hope and fear, beware of this letter,

If you notice, I said a rare word.

This rubai belongs to the pen of Mawlana Abdurahman Jami. Ali Safi wrote this after the rubai "Maxfiy qolmasun-kim, g'ayb-i huviyyatkim, hazrat Maxdumiy (Mavlono Abdurahmon Jomiy) bu ruboiyda aytibdurlar, tahqiqning istilohida iboratdur Zot-i Haqq subhonahudin lo ta'yin e'tibori bila, ya'ni itloq-i haqiqiy sharti bilakim, lafz-i itloq bila muqayyad emasdur va mumkin ermaskim, bu martabada hech ilme va idroke aslo anga taalluq topg'oy va bu haysiyyatdin majhul-i mutlaq turur". [6.39]

\section{CONCLUSION}

This is how Ali Safi interpreted the phrase "Ghayb-i Huwiyyat" in the rubai of Abdurahman Jami. This means that the meaning of the phrase "Ghayb-i Huwiyyat" is the Essence of Allah, and a member of the sect must always remember Allah.

\section{REFERENCES}

1. ال ح يات ع ين ر شحات . FA DAM Fund of the Republic of Uzbekistan Q.№33, -p. 20

2. Khoja Abdulkhaliq Gijduvani. Authority Yusuf Hamadoni. Will / Gijduvani dhikr 
in the sources. Tashkent:

"Transoxiana", 2018. -p. 96.

3. Tosun Necdet. BAHAEDDIN

NAKSBEND.Hayatı- Gorıslerı -Tarıkatı. Istanbul - Insan yayınlerı. -p. 334.

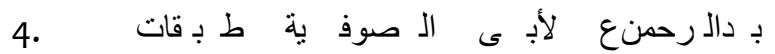

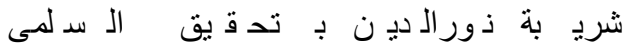

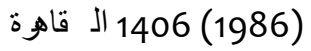

5.

6. Fakhruddin Ali Safiy. "Rashakhot aynuI-hayot". Drops of life. -T., 2004.-p. 38.

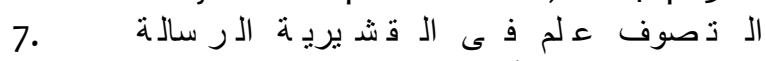

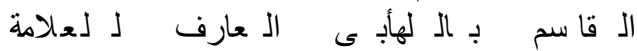

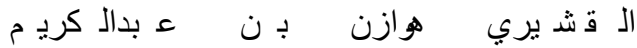

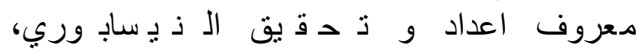

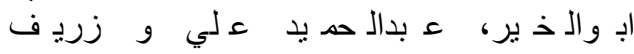

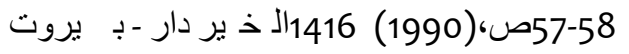

8. Mawlana Sa'duddin Kashgari. Risola dar kalima-i qudsiyya. Turkey, Sulaymaniyah Library, №1387, in Persian.

9. عطار علاءالدي ن خواجه مدقامات FAR SHI, №11399, -p. 160

10. Rashakhot (ال ح يات ع ين ر شحات). FA AM Fund of the Republic of Uzbekistan Q. №33, 11b c. 